\title{
Useful model № BG 2705 of special orthodontic retention apparatus
}

\author{
Mihaela Varneva \\ Department of Clinical Medical Sciences, Medical University, Bulgaria
}

Correspondence: Mihaela Varneva, Faculty of Dental Medicine, Department of Clinical Medical Sciences, Medical University, Prof. Dr. P. Stoyanov-Varna, 84,Tzar Osvoboditel“ Road,Varna, 9000, Bulgaria,Tel +359 898284677, Email divya.bakr@den.hmu.edu.iq

Received: October 06, 2017 | Published: October 31, 2017

Copyright@ 2017 Varneva. This is an open access article distributed under the terms of the Creative Commons Attribution License, which permits unrestricted use, distribution, and reproduction in any medium, provided the original author and source are credited.

\begin{abstract}
Summary
Orthodontic treatment is divided into two periods: active treatment period and retention one. Retention period duration depends on deformation severity, periodontium status as well as whether or not the facial growth has been completed. We consider the special removable retention apparatus popularized by Carlos Barberi ("ARCO Barberi-COBALT" abbreviated as "ABC") comfortable to be carried and enabling the maintenance of a good oral hygiene. We established that cobalt-chromium-nickel wire used in our country is not very popular and less accessible in terms of price and stock in stores selling materials and consumables in the city of Varna. This has prompted us to consider the possible changes in current materials and components of the retention apparatus in order to make it easier to use, faster to manufacture and less expensive. We accomplished our task and in December 2015, we registered our useful model № BG 2145 special orthodontic retention apparatus designed for the maxilla by the Patent Office of the Republic of Bulgaria. Almost two years later on, in 2017, we registered our useful model № BG 2705 special orthodontic retention apparatus designed for the mandible. The present article describes these apparatuses.
\end{abstract}

Keywords: Useful model № BG 2705 of orthodontic retention apparatus; Characteristics

\section{Introduction}

Orthodontic treatment is divided into two periods: active treatment period and retention one [1-4]. During the first period, usage of various orthodontic instruments results in certain tissue orthodontic changes in the periodontium. In order to maintain the new form until restoration of the changes in periodontium soft and hard tissues and to get adequacy with the new function, the therapeutic device should not be activated for certain period of time or the so-called orthodontic retention apparatus should be used [1-3,5-9]. The issue of storage and long-term stability of treatment results remains an important problem for orthodontics $[1,5,6,10,11]$.

There is a wide variety of retention apparatus in the medical literature available [2,3,7-10,12-14]. The choice of a suitable retention apparatus should be made during the planning and initiation stage of the treatment in order to ensure a stable outcome and to prevent recurrence. The variety of retention devices allows us to choose the most optimal ones $[1,5,8,10]$.

Retention apparatus can be special or curative. The activation of those of the second group has already been ceased. According to the mouth fixation manner, they can be removable or permanent [2,3,13-17].

The orthodontic retainers should meet the following requirements: to be passive, not to hinder occlusion, not to restrict free tooth movements, to be comfortable and not to hamper the patient, to be aesthetic, to allow for a good oral hygiene, and to be maintained in the oral cavity $[1,3,6,9,13,14]$.

Retention period duration depends on deformation severity, periodontium status as well as whether or not the facial growth has been completed. [1,5,13-16].

According to Persin, OSAMU retainer suggested by Dr. Osamu Yoshiiq in 1980 enables to open a "new page in the treatment concept during the retention phase". After entering the practice by the thermoforming technology, retainers with 1-1,5 mm-tick foils are elaborated which are drawn under pressure or vacuum.

They can span the tooth row or are free of chewing surfaces to prevent contact with the antagonists (Essex retainers) [1,6,8,18,19].

According to Mutafchiev, lingual wafers are the most commonly used mobile retention devices. They can be re-adjusted after treatment is completed or a new wafer is prepared. Quite often, a lingual wafer with a continuous vestibular arc is applied that passes tightly in the cervical region of all available teeth and behind the latter teeth it is lingually directed to fix in the plastic body. Wire thickness may be of $0.7 \mathrm{~mm} ; 0.8 \mathrm{~mm}$ and, rarely, of $0.9 \mathrm{~mm}[9,12,16]$.

Some authors introduce the term of "active" retention apparatus, such as an advantage of Hawley's wafer [1,6]. Because of this fact and of the long duration of the retention period, we were inspired to add elements enabling to catch up with the development of the facial skeleton, namely, maxilla and mandible.

Aim: to popularize the useful model of special, removable orthodontic retention apparatus for mandible № BG 2705 registered in the Patent Office of the Republic of Bulgaria, to describe its differences from „ABC“ and to prove its advantages. 


\section{Material and methods}

we have been acquainted with Carlos Barberi "ABC" retention apparatus and, using the knowledge and 34-year experience in orthodontic-dental practice, we have developed and registered at the Patent Office of the Republic of Bulgaria a useful model № BG
2145/1.12.2015 [20] and a useful model № BG 2705/31.08.2017 [21].

In order to prove the qualities of the useful model, we made a comparative analysis of the elements; materials; manipulations; instruments and apparatus for production of "ABC" and Useful model № BG 2705. The information is provided in (Tables 1-4).

Table I Comparison of the necessary materials for production of „ABC““ and Useful model № BG 2705

\begin{tabular}{|c|c|}
\hline „ABC“ Barberi & Useful model № BG 2705 Varneva \\
\hline I. Solid gypsum. & Solid gypsum. \\
\hline 2. Cobalt wire. & 2. Chrome-nickel steel wire. \\
\hline $\begin{array}{l}\text { 3.Chrome-nickel steel wire for reinforcement of the } \\
\text { plate part. }\end{array}$ & 3. Rose wax./pink wax/ \\
\hline 4. Glue wax. & 4. Spirits. \\
\hline 5. Rose wax (pink wax) & 5. Plaster plaster insulator. \\
\hline 6. Spirit. & 6. Plastic. \\
\hline 7. Packing substance. & 7. Expansion screw. \\
\hline 8. Solder. & $\begin{array}{l}\text { 8. Pliers, pastes and brushes for cleaning } \\
\text { and polishing of a plaque. }\end{array}$ \\
\hline 9. Flux. & 9. Separator for plastic. \\
\hline \multicolumn{2}{|l|}{ 10. Plaster plaster insulator. } \\
\hline \multicolumn{2}{|l|}{ I I. Plastic. } \\
\hline \multicolumn{2}{|l|}{$\begin{array}{l}\text { 12. Pliers, pastes and brushes for cleaning and } \\
\text { polishing the binders. }\end{array}$} \\
\hline $\begin{array}{l}\text { 13. Pliers, pastes and brushes for cleaning and } \\
\text { polishing of a plaque. }\end{array}$ & \\
\hline
\end{tabular}

Table 2 Comparison of the necessary instrument and apparatus for production of „ABC“ and Useful model № BG 2705

\begin{tabular}{ll}
\hline „ABC“ Barberi & Useful model № BG 2705 Varneva \\
\hline 1. Pliers. & 1. Pliers. \\
$\begin{array}{l}\text { 2. Burner/soldering apparatus. } \\
\text { 3. Apparatus for polymerization of plastic. }\end{array}$ & $\begin{array}{l}\text { 2. Apparatus for polymerization of plastic. } \\
\text { 3. Micromotor. }\end{array}$ \\
$\begin{array}{l}\text { 4. Micromotor. } \\
\begin{array}{l}\text { 5. Polarizer or other polishing machine of the plate } \\
\text { portion. }\end{array}\end{array}$ & \\
\hline
\end{tabular}

Table 3 Comparison of the elements of „ABC“ and Useful model № BG 2705

\begin{tabular}{lll}
\hline Elements & „ABC“ Barberi & Useful model № BG 2705 Varneva \\
\hline Vestibular arc & $\begin{array}{l}\text { Cobalt wire with a horizontal shoulder } \\
\text { on the incisor joined to Adams' hooks. }\end{array}$ & $\begin{array}{l}\text { Chromium-nickel steel wire with a horizontal } \\
\text { shoulder at the frontal teeth - incisors and canines, } \\
\text { with retention ends included in the plaque. }\end{array}$ \\
Hanging hooks & Cobalt wire Adams - 2 pcs. & Vertical hooks for interdental fixation - 2 pcs. \\
Plain part & $\begin{array}{l}\text { Reduced as in the lateral areas is about } \\
2-3 \mathrm{~mm} \text { above the cervix and covers a } \\
\text { small part of the oral crown surfaces. }\end{array}$ & $\begin{array}{l}\text { Reduced, as in the lateral areas, near the chewing } \\
\text { surface to the base of the tubercles, covering a } \\
\text { large part of the oral crown surfaces. }\end{array}$
\end{tabular}


(Table 3 continue..)

\section{Expansion screw}

Wire reinforcement no

Chromium-nickel steel wire lingually behind the frontal teeth.
Placed to catch the growth of the jaw.

no

Table 4 Comparison of the manipulations for production of “ABC” and Useful model № BG 2705.

\begin{tabular}{|c|c|}
\hline „ABC“ Barberi & Useful model № BG 2705 Varneva \\
\hline 1. Cast model deployment. & 1. Cast model deployment. \\
\hline 2. Bending of wire elements: & 2. Bending of wire elements: \\
\hline - Adams' hooks - 2 pcs. & - one-piece hooks - 2 pcs. \\
\hline - vestibular arc & - vestibular arc. \\
\hline 3. Bending the wire reinforcement. & 3. Isolation of the model. \\
\hline 4. Fixing the elements before welding. & 4. Fix (with wax) the wire elements of the model. \\
\hline 5. Soldering preparation. & 5. Placing of plastic. \\
\hline 6. Soldering-2 times. & 6. Installation of the expansion screw. \\
\hline 7. Cleansing and polishing of the binders. & 7. Polymerization. \\
\hline 8. Isolation of the model. & 8. Cleaning and polishing of the plaque. \\
\hline 9. Fix (with wax) the wire elements of model. & 9. Cutting the plate portion. \\
\hline 10. Placing of plastic. & 10. Washing and handing over in the office. \\
\hline \multicolumn{2}{|l|}{ 11. Install the wire reinforcement. } \\
\hline \multicolumn{2}{|l|}{ 12. Polymerization. } \\
\hline 13. Cleaning and polishing of the plaque. & \\
\hline 14. Washing and transferring to the office. & \\
\hline
\end{tabular}

\section{Results and Discussion}

Awareness of theory and practice helps us to find the special, removable, retention apparatus popularized by Carlos Barberi ("ARCO Barberi-COBALT" abbreviated as "ABC") suitable for maintaining and allowing for good oral hygiene.

The device is removable and, according to its author, can be used in the maxilla and mandible during the retention period. It consists of wire elements and a plaque. The wire elements are made of cobaltcontaining wire and include: discrete vestibular arc of $0.9 \mathrm{~mm}$ thick circular cross section. In the lateral portions, it is joined to the horizontal arms of two Adams' hooks (made on the first molars, which are included along with the retention arms in the reduced plaque [22]. Barberi uses this wire because it allows heat treatment $-450^{\circ} \mathrm{C} / 842^{\circ}$ $\mathrm{F}$ for about 5 minutes and does not change its properties [23] (Figure $1 \& 2)$.
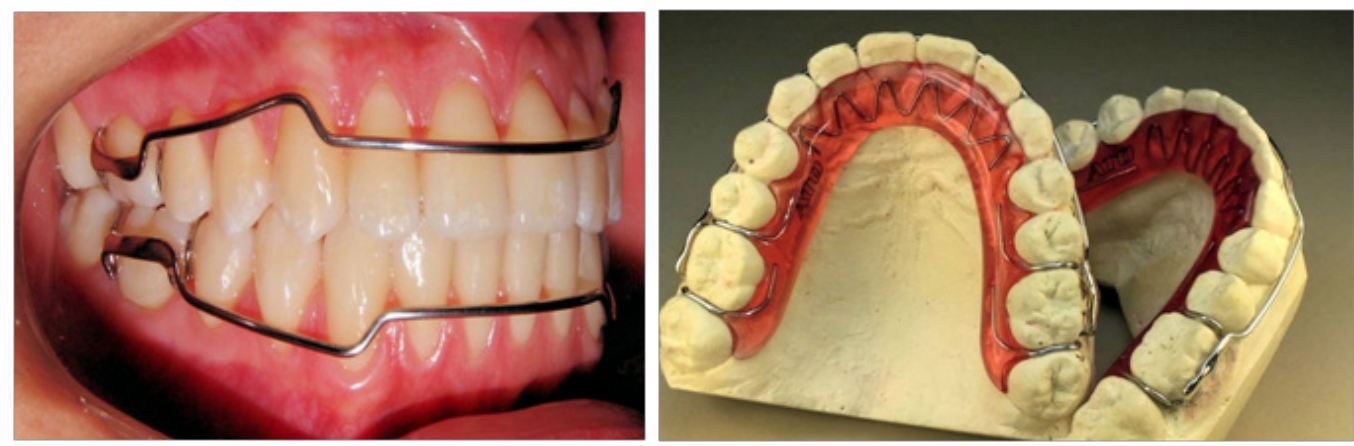

Figure I\&2 „ABC” [22]. 
We enjoyed the apparatus and decided to include it in students' curriculum of the dental technician specialty at the Medical University of Varna and in our practice as well. With great astonishment, we establish that cobalt wire is not very popular and it is more difficult to access.

This has prompted us to consider the possible changes in the materials used and the elements of the retention apparatus to facilitate its production by shortening the manufacture time needed and lowering its prime cost.

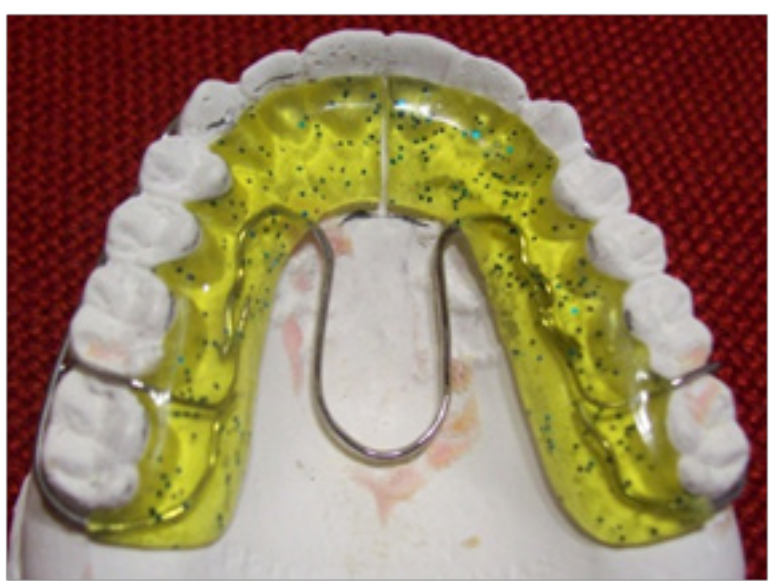

Figure 3 Maxillar reamer made on phantom model (own archive).
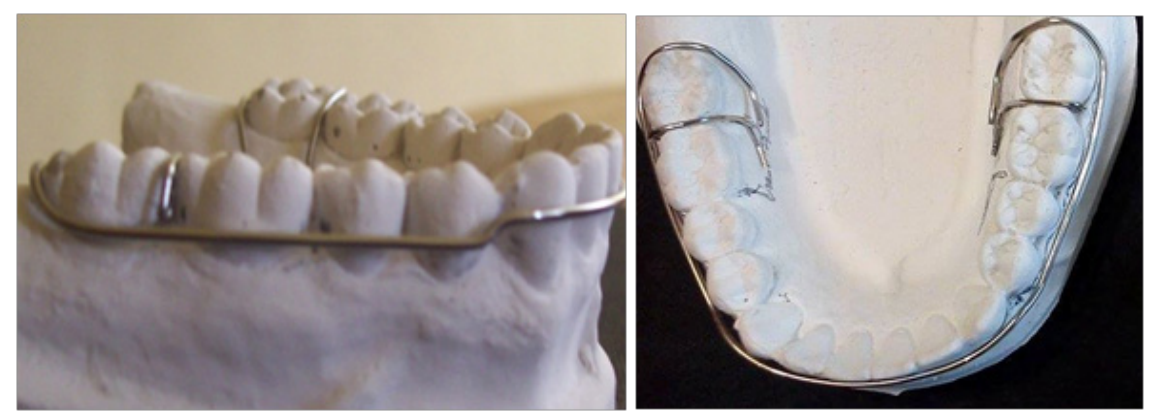

Figures 5\&6 Useful model № BG 2705 (own archive).
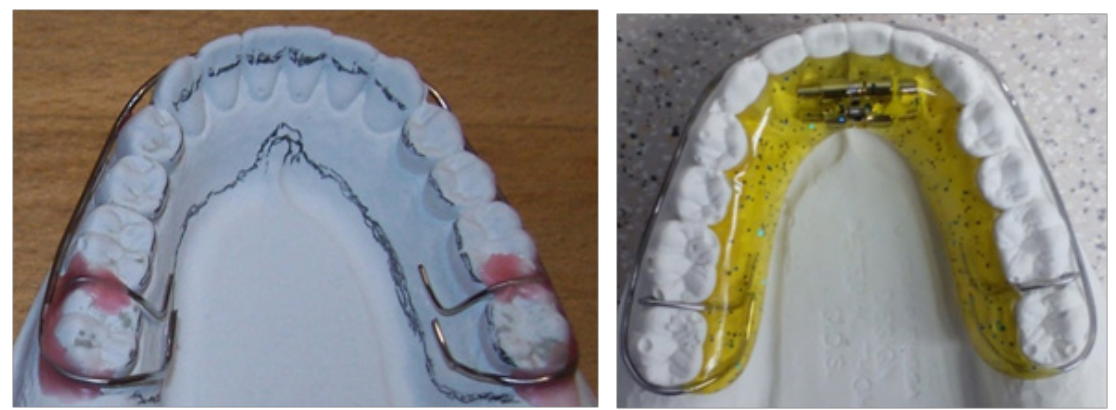

Figures 7\&8 Useful model № BG 2705 (own archive).

In 2015, we registered a useful model № BG 2145 orthodontic retention apparatus for maxilla (Figures 3\&4) [20,24].

In 2017, we registered the useful model № BG 2705 of a mandibular retention apparatus only because of the impossibility to simultaneously register the useful models for both maxilla and mandible due to some differences between their elements and the specific requirements of the Patent Office of the Republic of Bulgaria. The apparatus made of phantom models is shown on (Figures 5-8).

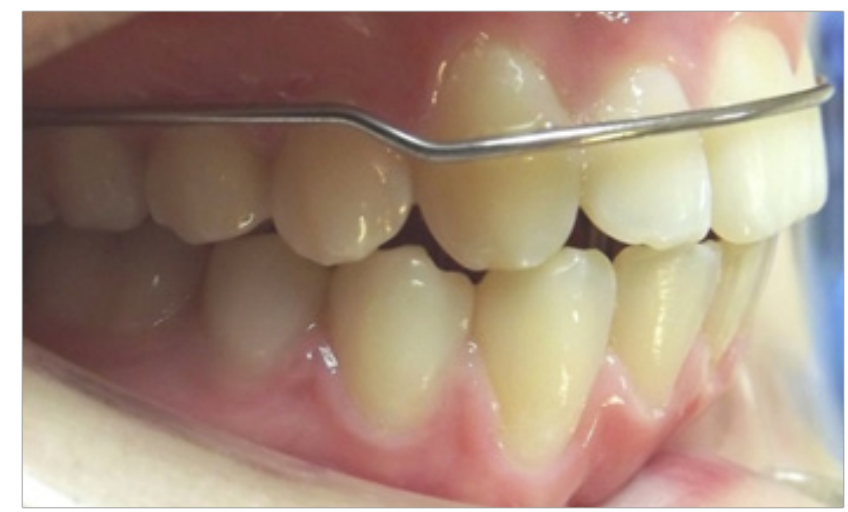

Figure 4 Retention apparatus applied in practice (2016) (own archive). 
Our proposals which enabled the registration of a useful model № BG 2705 are the following:

i. To make the vestibular arc, use a chromium-nickel steel wire with a round section and thickness of $0.9 \mathrm{~mm}$ (widely used in our country).

ii. Soldering should be avoided because of the use of chrome-nickel strand woolen wire (to maintain its elasticity and reduce prime cost).

iii. The vestibular arc encompasses the distal sides of the last available teeth (with occlusal arms) and is inserted into the plaque component with retention edges due to failure of brazing, such as manipulation.

iv. To modify vestibular arc bending in the frontal area by aligning it at the center of the crown of the first premolars (34 and 44) at an obtuse angle and pointing to the crowns of the frontal teeth by covering all frontal teeth $(33,32,31$ and $41,42,43)$ at the level of the dental papillae.

v. To add an extension screw behind the frontal teeth when the retention apparatus is used in a mixed dentition and when the development and growth of the organism as well as of the facial skeleton and jaws, respectively, continues. In this way, the device will be able to catch up with natural growth and development. It will be used for a longer period of maintenance of the therapeutic results achieved.

vi. To remove plaque wire reinforcement caused by the insertion of an expansion screw behind the frontal teeth.

vii. Plate is cut along the middle line to allow the expansion screw to dissolve and thus to catch up with jaw natural growth and development.

To perform and improve retention under useful model № 2705, we offer the following:

I. Use one-legged, loose interdental clamping hooks' fixation by means of interdental spaces in premolars and molars (left and right).

II. Extend the boundaries of the plaque in the area of premolars and molars (to the chewing plane, to the tubercle basis).

If the patient is at young age at which the jaw growth is completed, no expansion screw is required at all.

a. Based on the comparative results presented, the following conclusions about the advantages of the useful model suggested by us could be drawn:

b. The vestibular arc encompasses all frontal teeth, which allows the retention not only of the incisors, but also of teeth 33 and 43 in the new position after treatment.

c. The use of an expansion screw allows mandibular growth and development to catch up, which allows a longer application of the retention apparatus.

d. In the manufacture, chromium-nickel steel wire with round section is widely used in our country. e. Less materials, consumables, tools and devices are used, making it easier for dental technicians.

f. It takes a shorter production time.

g. The prime cost of the apparatus is reduced, which reduces the final cost to the patient.

The useful model № BG 2705 of a special, removable orthodontic retention apparatus for the mandible is discrete, comfortable to wear, allows for good oral hygiene. That is why we believe that it will find its worthy place in orthodontic practice and theory.

\section{References}

1. Alimova M Ya, IM Makeeva. Orthodontic retention apparatus. MEDpresInform. 2009;p:70.

2. Dekova L, Apostolova V, Mladenova D. Atlas of Orthodontics. Sofia, Medicina i fizkultura Publishing House. 1988;p:122 (in Bulgarian).

3. Gesheva N, Nikolov B, Dekova L. Orthodontics. Sofia, Medicina i fizkultura Publishing House. 1978;p: 185-187 (in Bulgarian).

4. Koev Zh. Tooth-jaw deformations. Sofia, Medicina i fizkultura Publishing House. 1961;p:170 (in Bulgarian).

5. Flyse PC. Orthodontics. Kiev, Medicina. 2016;p:357 (in Russian).

6. Khoroshilkina F Ya. Orthodontics. Textbook for postgraduate training in specialty of dentistry. $2^{\text {nd }}$ revised and enlarged edition. Moscow, Medical News Agency. 2010;p:555 (in Russian).

7. Peev T. Dental prostheses and orthodontic appliances. Sofia, Medicina i fizkultura Publishing House. 1997;p:351 (in Bulgarian).

8. Persin LS. Orthodontics - manual for physicians. Moscow, Medicina. 2004;p:259 (in Russian).

9. Varneva M. Elaboration of special, removable retentive apparatus (of wafer type) after completion of the orthodontic treatment (case study). Dental Labor. 2016;5(1):27-31 (in Bulgarian).

10. http://stomport.ru/articles/osnovnye-etapy-izgotovleniya-semnyh-inesemnyh-ortodonticheskih-retencionnyh-apparatov.

11. Zachrisson BU. Important aspects of long-term stability. J Clin Orthod. 1997;31(9):562-583.

12. Mutafchiev V, Krumova V, Yordanov V. Orthodontics for general practitioner dentist. Sofia, Nemesida, 2003;p:477-481 (in Bulgarian).

13. Varneva M. Application in orthodontic practice of the useful model No 2145 (special removable retention apparatus). In: VIII International Scientific and Practical Conference "Actual Problems of Science of the $21^{\text {st }}$ Century". Proceedings, Part 2, International scientific organization "Cognito", Moscow, 2016;p:8-13 (in Russian).

14. Varneva M. Useful model No 2145-retention apparatus. Center for Scientific Cooperation "International Scientific Research". ISI-journal, Moscow. 2016;6:123-128 (in Russian).

15. Krumova V. Orthodontics manual for students. Sofia, Medicina i fizkultura Publishing House. 2012;p: 120-122 (in Bulgarian).

16. Tupankov A, Taskova Ts, Svetoslavova G. Retaining apparatus - types. Thermoforming technology for making a removable retentive apparatus. Varna Medical Forum. 2016;5(Suppl 4):132-138 (in Bulgarian).

17. Yordanova SM, Yordanova-Chaprashikyan. Manual for dental technicians. IC-VAP, Plovdiv. 2012;p: 126 (in Bulgarian).

18. http://www.erkodent.de/f30fbb5206dacbe47a4d4483619562c9.pdf. 
19. http://www.erkodent.de/995154890f9971c9251f51a467d4dbbf.pdf.

20. Bulletin of the Patent Office, No 11/1.12.2015. Description for registration of useful model No BG 2145, Sofia, Republic of Bulgaria. 2015 (in Bulgarian).

21. Bulletin off the Patent Office, No 8/31.08.2017. Description for registration registration of a useful model No BG 2705, Sofia, Republic of Bulgaria. 2017 (in Bulgarian).
22. https://ortopediayortodoncia.com/tag/carlos-barberi

23. http://www.dentaurum.de/files/989-771-00_Draht_2005_EN.pdf

24. Kopeikin VN, Demner LM. Dental prosthetics (for students of medical schools). Moscow, Medicina. 1985;p:361 (in Russian). 